\title{
Article
}

\section{Strategic responses to global challenges: The case of European banking, 1973- 2000}

Larson, Mitchell Jonathan, Schnyder, Gerhard, Westerhuis, Gerarda and Wilson, John

Available at http://clok.uclan.ac.uk/3258/

Larson, Mitchell Jonathan ORCID: 0000-0002-5506-0815, Schnyder, Gerhard, Westerhuis, Gerarda and Wilson, John (2011) Strategic responses to global challenges: The case of European banking, 1973-2000. Business History, 53 (1). pp. 40-62. ISSN 0007-6791

It is advisable to refer to the publisher's version if you intend to cite from the work. http://dx.doi.org/10.1080/00076791.2011.546660

For more information about UCLan's research in this area go to http://www.uclan.ac.uk/researchgroups/ and search for <name of research Group>.

For information about Research generally at UCLan please go to http://www.uclan.ac.uk/research/

All outputs in CLoK are protected by Intellectual Property Rights law, including Copyright law. Copyright, IPR and Moral Rights for the works on this site are retained by the individual authors and/or other copyright owners. Terms and conditions for use of this material are defined in the policies page.

\section{CLoK}

Central Lancashire online Knowledge www.clok.uclan.ac.uk

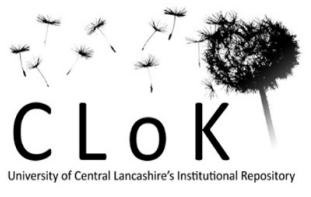


Strategic responses to global challenges - the case of European banking, 1973-2000

Mitchell J. Larson ${ }^{\mathrm{a}}$, Gerhard Schnyder ${ }^{\mathrm{b}}$, Gerarda Westerhuis ${ }^{\mathrm{c}}$ and John Wilson ${ }^{\mathrm{d} *}$

${ }^{\mathrm{a}}$ Lancashire Business School, University of Central Lancashire, Preston, UK

bManagement Department, King's College London, UK

${ }^{c}$ Research Institute for History and Culture, Utrecht University

${ }^{\mathrm{d}}$ University of Liverpool Management School

\begin{abstract}
In applying an SSOP (strategy; structure; ownership; performance) framework to three major clearing banks (ABN AMRO; UBS; Barclays), we debate whether the conclusions generated by Whittington and Mayer about European manufacturing industry can be applied to the financial services sector. While European integration plays a key role in determining strategy, it is clear that global factors were far more important in determining management actions, leading to significant differences in structural adaptation. We shall also debate whether this has led to improved performance, given the problems experienced with both geographical dispersion and diversification, bringing into question the quality of decision-making over the long-term.
\end{abstract}

Keywords: ABN AMRO; UBS; Barclays; banks; SSOP framework; strategy; structure; ownership trends; bank performance; European integration; financial liberalisation.

*Corresponding author john.wilson@liv.ac.uk 


\section{Notes on Contributors.}

Gerarda Westerhuis is Postdoc Researcher at the Research Institute for History and Culture, Utrecht University, The Netherlands. Her most recent research focuses on the corporate governance and the financing of business in the Netherlands during the 20th century.

John Wilson is Professor of Strategy at the University of Liverpool Management School, where he is Director of Programmes and Head of the Centre for International Business. 


\section{Strategic responses to global challenges - the case of European banking, 1973-2000}

Although over the course of the last thirty years European banking has undergone a series of dramatic changes, providing fascinating insights into the interactions between strategy, structure, ownership and performance (SSOP), few SSOP studies have been conducted into this sector (one exception being Channon 1977 and 1986). The essence of this transformation was the move from highly regulated, national banking sectors towards an integrated financial sector, with the 1980s acting as the watershed decade. Based on case studies of three major banks in Great Britain (Barclays), the Netherlands (ABN AMRO) and Switzerland (UBS), we gain valuable insights into how this sector made these moves. As ABN AMRO and UBS were the result of major mergers in 1990 and 1998, respectively, we also include their precursor banks prior to the merger. In particular, it will become clear that while the European integration process was a key factor in explaining certain strategic adjustments, the key to understanding European banking changes at that time will revolve around more global stimuli, including global tendencies in the financial sector, the liberalisation of financial markets, and a series of traumatic crises that severely affected attitudes within and to banks.

The choice of these three banks is explained by their particular position in European banking. While the UK clearly is the leading financial centre in Europe, banks from Switzerland, and from the Netherlands have experienced tremendous growth over the last decades and were ranked in 1999 among the top 50 banks world-wide (UBS 8th, Barclay's 13th and ABN AMRO 22nd, according to market capitalisation as of 31 May 1999) (Financial Times, 23 March 2009). Compared to GDP, the two smaller countries were consequently among the most important financial centres in Europe, having reached this position through aggressive expansion strategies, which make them particularly interesting cases for this study. Although not entirely representative of the banking sector in each country, they are among the dominant banks in each country which reacted most decisively and aggressively to the new challenges.

Starting with a brief discussion of the overall background, we shall then move on to chart the key changes to each bank's strategy, structure and ownership over the period 19732007, taking five benchmark years (1973, 1983, 1993, 2003 and 2007), supplemented by qualitative analyses of their growth patterns. This will provide dynamic insights into the interaction between the various contemporaneous challenges and opportunities and the tendency towards convergence in European banking. Above all, we shall demonstrate that the banking sector differed in several significant respects from the manufacturing industries analysed by Whittington and Mayer (2000). It is important to stress that due to the particular characteristics of the banking sector, it has been essential to adapt various dimensions of their analytical framework. For example, while in order to determine strategy Whittington and Mayer (2000) use the percentage of total turnover, we adapt this measure by simply comparing the percentage of total net income attributable to interest business vs. non-interest business. A finer distinction between different non-interest businesses will only be undertaken qualitatively. Crucially, though, while Whittington and Mayer (2000; 153-55, 187-8) substantiate the Chandlerian model, which claims that big manufacturing businesses pursued diversification strategies, leading to the extensive adoption of an M-form structure, the banking sector is clearly different. Indeed, we will show that particular needs in terms of risk management seem to create incentives for banks to resist far-reaching decentralisation of the organisational structure. Secondly, it is also apparent that in response to the creation of a 
European Single Market in 1993 banks did not revert to core business activities, as Rondi et al (2004) discovered for the manufacturing sector. In the conclusion, we will assess the reasons behind these differences, as well as discuss how this impacted on conventional measures of performance, providing insights into the extent to which banking compares with other sectors when applying the SSOP framework.

\section{The institutional environment.}

While a comprehensive analysis of European banking history is not necessary at this stage, it is vital to outline the key developments that impinged directly on the strategic direction of key institutions. In this context, undoubtedly the first major stimulus was American competition, as banks which had followed American manufacturing multinationals across the Atlantic started to extend their range of services and compete directly with the indigenous sector (Sylla 2002). This 'invasion' has been extensively analysed in the essays edited by Battilossi \& Cassis (2002), which outline how it was especially acute in the eurocurrency market and investment banking, although dynamic banks such as Citibank were keen to encroach on any markets that would enhance their profitability. Channon (1986) has also explained how US banks decisively influenced the cosy banking cabals that had previously dominated European banking, injecting a degree of dynamism that had been lacking. Furthermore, not only did these moves stimulate a strategic response from European banks, a point we shall assess in the case-study sections, but as the American banks had already demonstrated the extensive advantages of investments in computerised banking, this prompted increased imitation in Europe. Although many banks had started investing in information technology after 1960, the introduction of credit cards, automated telling machines, and intense processing of customer information and cheques compelled banks to invest heavily in the new technology. This contributed extensively to improved productivity in European banking. Indeed, it became an essential dimension of corporate strategy from the 1960s, because in response to decisive corporate governance changes, management strove to reduce costs and increase dividends as an essential means of maintaining shareholder loyalty (Canals 1993).

In addition to the dual impact of increased American competition and technological innovation, another key feature of the institutional environment of that era was the increased degree of economic integration in Europe. Although the Treaty of Rome that created in 1957 the original Common Market of six countries (West Germany, France, Italy, Belgium, Netherlands and Luxembourg) was principally a trading group, from the 1970s increased attention was focused on harmonising a wider range of economic activities. The first European Banking Directive was passed in 1977, by which time the UK had joined what was called the European Community (EC), while a second was passed in 1989. Even though some countries retained their own distinctive regulations, the key feature of the EC initiatives aimed to facilitate cross-border banking. Of course, this ran parallel to the general liberalisation and deregulation of financial markets in the USA and Western Europe, a trend that had started with the election of a Conservative government in the UK in 1979 and spread progressively across the Western world thereafter. In addition, the second European Banking Directive attempted to lay the financial basis for the establishment of the single European market in 1992, creating enormous opportunities for firms of all types in exploiting muchexpanded and relatively wealthy markets (Canals 1993). One important change related to the single European market concerned the introduction of the single banking licence, according to which any bank with a licence to operate in any EU member country could automatically become active in other EU member countries. This significantly increased competitive 
pressures on European banks. It is also important to add that during the 1990s a process of liberalisation in the US banking sector led to the enactment of the Riegle-Neal Interstate Banking and Branching Efficiency Act in 1994 and of the Gramm-Leach-Blilley Act in 1999. Consequently, a consolidation wave hit the USA, prompting the creation of large financial conglomerates which exerted enormous competitive power in both the American and European markets (Calomiris 2000, 2002; Kroszner 2001).

One can consequently detect how over the course of the late twentieth century European banks were faced with a range of both fresh opportunities and key competitive stimuli. It is also important to stress that one of our case-studies originates in Switzerland, an economy that has never been a part of the European Community; not only were Swiss banking regulations shadowing those of the EC, but American competition also affected that country's stable financial sector. Indeed, the three case-studies illustrate a degree of commonality, not least in terms of strategic responses to the rapidly changing institutional environment, and especially in searching for new market opportunities in a range of locations.

\section{UBS and SBC: Strategy, structure and ownership 1973 - 2007.}

The UBS AG, until recently Switzerland's largest bank and the world leader in wealth management, has emerged from a process of continuous concentration within the Swiss banking industry that had arguably started during the late nineteenth century. The bank took its current form in 1998, when two major Swiss banks, the Swiss Banking Corporation (SBC, Schweizerischer Bankverein, SBV) and the old UBS (Schweizerische Bankgesellschaft, SBG), merged. SBC dates back to a consortium of six private banks that was created in Basel in 1854. Through a series of acquisitions, it became a major bank in Switzerland and established its first office abroad in 1898 in London. UBS, on the other hand, emerged in 1912 as the result of a merger between two regional banks from the eastern part of Switzerland; it was first headquartered in Winterthur and later in Zurich. UBS remained a smaller and much less internationalised bank than SBC, opening its first foreign representation in New York only in 1946.

\section{Strategy}

Up until the 1980s, traditional lending was the dominant business (defined as one which amounts to at least 70\% of total turnover, but less than 95\%) of both UBS and SBC: interest income amounted to $72.25 \%$ of UBS's income in 1973 and $69.70 \%$ in 1983, while SBC's corresponding figures were $71.49 \%$ and $71.61 \%$. Up to the 1980 s, the internationalisation of the two Swiss banks was limited: in 1973, only $2.17 \%$ of UBS's branches were abroad and 4.48\% of SBC's; and by 1983, these figures had only moderately increased to $3.21 \%$ for UBS and $6.17 \%$ for SBC, corresponding to $3.96 \%$ and $11.24 \%$ of total staff, respectively. Prompted by increasingly competitive domestic and international markets and falling profitability in the traditional lending business, both banks initiated a fundamental change in strategy during the 1980s. Several factors explain this strategic shift. Firstly, banks faced increasing competition from insurance companies for both household savings and newly-created compulsory occupational retirement plan savings (Ravara 1999: 6). As households increasingly turned away from the classic bank account, an important and - given Switzerland's low interest rates - cheap source for refinancing for banks started to dry up (Wirth 1993). Secondly, during the 1980s many Swiss companies, whose capital basis had been eroded during the crises of the 1970s, increasingly turned to a booming stock market in 
order to raise cheap funds. This trend towards a 'disintermediation' of corporate finance put considerable pressure on interest margins, which were very low in Switzerland throughout the 1980s (Wirth 1993: 123). Thirdly, the deregulation of the financial industry, spurred by international developments, created a realistic takeover threat from foreign competitors, which led Swiss banks to believe that only an increase in size could ultimately guarantee survival. The major Swiss banks consequently adopted a strategy aimed at becoming 'global players' (Schaub 1992).

A fourth factor also indicated a fundamental shift in competition, because while Switzerland was not a member of the EU, EU law has had an increasingly strong influence on Swiss practice. The impact of EU banking directives was almost as direct on Switzerland as in the two other countries. Indeed, during the 1980s some form of association between Switzerland and the EC/EU was expected by most economic actors, notably in relation with the negotiations of the European Economic Area Agreement. In 1989, the Swiss government deposited a (non-activated) membership request with the EU. The anticipation of membership and the fear of being disadvantaged in the European common market generated a sentiment among policy makers that Swiss law should follow EU legislation as closely as possible. Therefore, non-membership does not imply that the EU-level changes in banking and financial market regulations were irrelevant for Switzerland. As Graf (1993a: 68) states, '[a]t least since 1989 no regulatory change took place [in Switzerland] which was not influenced by the relevant EC Directives'. In particular, the EU's influence was strongly felt in the field of competition policy, where Switzerland was notorious for being 'the unmatched world champion of cartels' (Schröter 1996: 149). In 1989, following a report by the Swiss Cartel Commission, several agreements of the Swiss Bankers Association that fixed minimal fees for certain services were abolished (Federal Cartel Commission 1989). This increased competition among Swiss banks and put greater pressures on profitability (Graf 1993b). In addition, the adoption of the EU's Second Banking Directive in 1989, which introduced the 'single licence', fostered the feeling among Swiss bankers that an increase in competitiveness was highly desirable, given that Switzerland was then considered likely to be joining the European Economic Area (EEA). Although the 1977 Directive had not led to any legal changes in Switzerland, such was the importance of EC law that the Swiss Banking Act (dating from 1934) was revised in 1994 in order to integrate the Second Banking Directive into Swiss law.

In response to these multiple pressures, both UBS and SBC elaborated at the end of the 1980s a range of different strategy papers which set out the ways in which the challenges could be met. Besides the adoption of bancassurance strategies, these new policies consisted in both cases of a double-edged strategy: aggressively expand in the home market through acquisitions, in order to secure an increasing part of a shrinking deposits market (Graf 1993b: 132), and expand abroad in investment banking, and asset- and wealth-management (but not in retail banking). From the mid-1980s until the merger in 1998, though, the two banks pursued different strategies of international expansion and diversification. In SBC's case, its strategy aimed at becoming one of the world's top-10 banks through a series of mergers and acquisitions. Four landmark acquisitions were particularly important for the implementation of this strategy: O’Connor \& Associates (1992), Brinson Partners (1994), S.G. Warburg (1995), and Dillon Read (1997) (Leitz 2008: 10). In contrast, UBS’s strategy was implemented mainly through internal growth, which explains the absence of any major acquisition up to the mid-1990s (Leitz 2008). This process of internationalisation significantly increased the proportion of their staff employed abroad, in SBC's case to $18.93 \%$ in 1993 (compared to $11.24 \%$ in 1983), while UBS's rose to $21.83 \%$ (up from 
3.96\%). Alongside these strategies, related diversification was also pursued, an indication of which was that by 1993 only 33.06\% of UBS's and 34.13\% of SBC's income stemmed from interest-earning activities. In terms of Whittington and Mayer's (2000) categories, both banks had adopted (related) diversified strategies, reducing their dependence on the formerly dominant lending business.

In 1998, the two banks announced their merger. This move arose mainly because UBS was unable to fend off a hostile takeover attempt by Swiss financier and corporate raider Martin Ebner. Ebner's investment company, BK Vision, had pressured the bank's management to adopt a more profitable, shareholder-oriented strategy, requiring management to impose a RoE [return on equity] goal of at least $18 \%$ and significantly cut its workforce (Loderer and Zgraggen 1998; Burkhalter 2001). By late 1997, a defensive merger with SBC seemed the only way to escape the raider's grip. Indeed, the renowned Neue Zürcher Zeitung (NZZ) considered the merger between UBS and SBC, which was announced in December 1997, to be a capitulation of the old UBS management in the face of a raider, as 'the new UBS meets in all respects BK Vision's expectations' (NZZ, 24 January 1998, quoted in Burkhalter 2001: 188). The new UBS introduced profitability goals of an $18 \%$ RoE and announced a reduction in staff numbers. This focus on increased profitability after the merger spurred further strategic change, because in 2003 UBS still generated 36.2\% of its income from traditional interest-earning businesses, a proportion that dropped dramatically to just $15.94 \%$ in 2007. Non-interest income business had consequently become the dominant strategy of the bank within twenty years (62.49\% in 2003; 84.06\% in 2007). In parallel, the share of foreign employees had increased from 18.93\% for SBC and 21.83\% for UBS in 1993 to $59.56 \%$ in 2003 and $68.72 \%$ in 2007 .

Analysts considered the new bank's strategy to be both successful and conservative, as its reliance on wealth management made it more robust in the face of volatile stock markets during the early 2000s (Müller-Stewens and Shivacheva 2006). Indeed, by 2003 UBS had become the world's largest wealth manager. Yet, this success induced UBS management to reach for new horizons: UBS CEO Peter Wuffli announced in 2003 that the new goal was to become the world's largest investment bank by pursing high-risk strategies (Müller-Stewens and Shivacheva 2006). The acquisition of PaineWebber in 2000, which had far-reaching expertise in mortgage-backed securities, made UBS the largest player in this field, effectively complementing its other strategies.

\section{Structure}

Before the 1980s, given the relatively limited scope of their activities, both banks had mainly regional structures, dividing their business into domestic and overseas units. While headquarters certainly did delegate some operational responsibilities to the divisions, this structure can hardly be considered a truly multidivisional form (Schaub 1992). In particular, profit responsibility remained concentrated at the centre. With the expansion of their businesses, however, both geographically and with regard to product diversification, restructuring became a regular occurrence. This is particularly true for SBC, which faced the challenge of integrating several major banks. In 1987, SBC substituted its regional structure for a truly multidivisional form based on four 'groups' - commercial banking, finance, investment and logistics. This was followed in 1994 by another major overhaul that witnessed the formation of a corporate centre for all support activities; two new business units, 'Switzerland' and the 'International \& Finance Division'; and a 'Group Executive Board' (GEB) as well as an 'Enlarged GEB'. This reshuffling constituted a step towards 
increasing decentralisation, as the divisions were given full profit responsibility for their respective markets (Annual Report SBC 1993: 13). Within the business unit 'International \& Finance', there were three regional management committees for 'Europe/Middle East/Africa', 'Americas' and 'Far East'. In effect, then, the structure can best be described as a matrix structure, although this was not the explicit goal, but rather a result of simultaneously increasing the importance of foreign markets and new products. The regional aspect, however, was reduced again in 1997, when four divisions were created: besides the corporate centre, there was now SBC Switzerland, including wholesale commercial banking in Switzerland and abroad, a wealth management unit called SBC Private Banking, an asset management unit (SBC Brinson), and an investment banking unit, SBC Warburg.

Given the strategy of internal growth rather than through cross-national acquisitions, UBS experienced fewer structural shake-ups. Nevertheless, a major restructuring took place in 1991, when UBS adopted a matrix structure, dividing its business into five geographical regions (Switzerland, Europe, North America, Japan, East Asia) and six divisions (Schaub 1992: 207). After the 1998 merger, the new UBS was first divided into five divisions, following which in 2000 it was converted into three units: UBS Switzerland, UBS asset management, and UBS Warburg (Muller-Stewens and Shivacheva 2006). In 2003, these divisions moved closer together, when the 'One Firm' strategy was adopted, which not only introduced a single brand across markets and products, but also encouraged cooperation between divisions (Mueller-Stewens and Shivacheva 2006: 6). This type of multidivisional form with structures that encouraged informal and 'unmanaged' exchanges between divisions appertain to a recent variety of the M-form, which Whittington and Mayer (2000: 182) call the 'network multidivisional'. In the wake of the sub-prime crisis, however, the 'One Firm' structure was revised in 2008. This structure - previously seen by a former chairman, Marcel Ospel, as the bank's core competence, by offering its clients a large range of top quality banking services through an integrated structure (Muller-Stewens and Shivacheva 2006: 9) was now deemed to be so fraught with weaknesses that there was a 'blurring of the true riskreward profile of individual businesses', creating the 'source of substantial risk, as we have seen in the past few months' (UBS communiqué, 12 August 2008). The new structure gave the three business units - Global Wealth Management \& Business Banking, Investment Banking, and Asset Management - much more autonomy and greater responsibilities, reducing the prospect of bad results in one area affecting the others.

\section{Ownership}

With regard to ownership, no systematic data is available prior to 1993 due to the absence of disclosure requirements. It appears, however, that the largest Swiss banks were for most of their history public companies without any share blocks held by strategic investors. Survey data provided by Bank Julius Bär (1991) for 1990 show that both UBS and SBC were widely-held companies without a blockholder possessing $5 \%$ of the shares or more. This changed during the early 1990s, because a survey carried out in 1996 (Bank Julius Bär 1996) shows that by 1995 both banks had a blockholder: the insurance company Zurich held $5.20 \%$ of SBC's capital ; and one of Martin Ebner's investment companies held 11.4\% of voting rights and $7.5 \%$ of the total capital of UBS. At that point, both banks were owned by a financial institution, according to Whittington and Mayer's (2000: 192) definition. After the merger in 1998, Ebner's stake decreased to just 1.2\% and the new UBS was again a widelyheld company, although foreign institutional investors started to acquire larger blocks.

\section{ABN AMRO: Strategy, structure and ownership 1973 - 2007.}


ABN AMRO's history dates back to 1824, when King Willem I issued a royal decree creating Nederlandsche Handel-Maatschappij. This was the earliest predecessor of ABN AMRO, with the objective of reviving trade between the Netherlands and the Dutch East Indies. Forty years later, Rotterdamsche Bank, Amsterdamsche Bank and Twentsche Bank were established. All four banks have played an important role in financing trade and in the development of Dutch industry. Mergers in 1964 between the four commercial banks led to the formation of Algemene Bank Nederland (ABN) and Amsterdam-Rotterdam Bank (Amro), both of which expanded into various countries and diversified into commercial banking, investment banking and private banking. In 1990, another merger led to the formation of ABN AMRO, which until recently was the largest bank in the Netherlands.

\section{Strategy}

The corporate strategy of ABN AMRO and its forerunners, ABN and Amro, can be characterized by consolidation, diversification and internationalisation. While they had traditionally focused on short-term trade credit, after the emergence of ABN and Amro in 1964, they started to diversify into retail banking, building an extensive domestic branch network to attract retail clients. This strategy was reinforced by the difficulties encountered by mortgage banks in the early 1980s, following which the Dutch central bank allowed banks and insurance companies to intervene in this sector, provided that they improved the equity of these banks. At the same time, while Amro gradually expanded its investment banking activities, ABN focused on international expansion, taking over Hollandsche Bank Unie in 1968, a bank with a strong presence in South America, and creating its own international branch network. Because of setbacks - specifically, the independence of the former Dutch colony of Indonesia and political unrest in Africa and South America - this strategy had to be changed in the early 1970s, with much greater emphasis being placed on Western Europe and the USA. The ABN board was of the opinion that 'to survive' the bank had to become one of the largest banks in the world, leading to the acquisition in 1979 of LaSalle National Bank (Chicago, Illinois), after which many other acquisitions in the USA followed (Westerhuis 2008). In contrast, Amro relied on cooperation with foreign banks through the European Banks' International Company (EBIC) (van Zanden and Uittenbogaard 1999), which was a less expensive and relatively safe way to expand abroad. Both Dutch banks consequently adopted internationalisation and diversification strategies earlier than the Swiss banks, principally because of imperial linkages that also influenced British banking traditions.

Growth remained one of the main pillars of strategy of ABN and Amro during the 1980s. During the 1980s, however, a merger with or takeover of a Dutch bank was prevented by the opposition of the Dutch central bank. In consequence, after a failed attempt to merge with Belgian Generale Bank in 1987, Amro enlarged its domestic investment banking activities, as well as sustaining its strategy of collaborating with other European banks, while ABN continued to pursue its international strategy. This reveals how by the late 1980 s ABN and Amro had been converted from commercial operations into banks that offered a whole range of products, with a country-wide branch network. At the same time, because the banks' net interest income was above 70 per cent, we can conclude that both adopted a dominant strategy in which traditional banking activities still prevailed. The main difference in strategy was the overseas orientation of ABN's strategy, as opposed to the domestic preference of Amro, because in 1983 32\% of ABN's employees were overseas, compared to only 5\% of Amro's employees (Annual Reports, 1983). 
In spite of their expansion efforts, $\mathrm{ABN}$ and Amro failed to climb the world ranking lists. In 1989, ABN dropped to 48 and Amro to 46 on The Banker's World Top 500 (measured by assets). With the onset of the Single European Market in 1993 and the extensive deregulation of financial transactions during the 1980s, this made them relatively easy takeover targets, prompting thought about greater concentration within Dutch banking. Just as in the Swiss case, increased domestic competition from foreign, mainly American, banks was also a cause of growing concern, while deregulation across Western Europe and the USA was prompting increased competition in all markets. This persuaded the Dutch central bank to encourage an increase in both the operating scale of Dutch banks and an extension of product portfolios, while in 1988 the supervision of inter-banking relations was relaxed and two years later banks and insurance companies were allowed to merge. The subsequent consolidation process resulted in the emergence of a few large financial conglomerates (de Leeuw 1996), with ABN and Amro merging into ABN AMRO in 1990. These financial conglomerates extended their product portfolios to fee-based products in response to the increased pressure on interest income.

The 1990 merger between ABN and Amro at least achieved one aim, in that it allowed the bank to climb to number 16 in the world rankings. Whereas ABN and especially Amro had been active in investment banking in the home market, it became an even more important part of ABN AMRO's growth strategy after 1990. ABN AMRO's objectives were to become a universal bank, with the Netherlands as its home market, but operating across Europe and in the USA, demonstrating that international expansion was very much at the heart of its strategy. Indeed, an international acquisition strategy was pursued, particularly in the USA, where several banks were purchased (Westerhuis 2008), and in South America by the acquisition of Banco Real in 1998. By 1998, the bank operated in 74 countries (Berendsen 1999).

Underpinning this internationalisation was the pursuit of improved shareholder value, especially since 2000 when the bank announced its decision to focus on core businesses in order to divest unproductive activities and to cut costs. Given that a consolidation wave hit the European continent at the time, the most important reason for the focus on shareholder value was the fear of becoming a target in the market for corporate control. This focus had major implications for the entire organization, because formal methods to value people and activities were introduced. In the Netherlands, the bank started closing local offices and laying off employees, with the specific aim of reducing costs as well as putting more resources into the most profitable activities. At the same time, the bank reformulated its goal of becoming a universal bank by stressing its preference for being a global investment bank, even though an internal assessment revealed that retail banking was much more profitable than investment banking (Smit 2008, Jonker 2008). This resulted in yet another reformulation of strategy, with non-interest income increasing from 48\% in 2003 to $60 \%$ in 2007, compared to just $37 \%$ in 1993, as the bank sought to build a bigger share of the middle class market. International expansion also remained an important pillar of strategy, with the share of foreign employees increasing from 38\% in 1993 to 77\% in 2007 (ABN AMRO Annual Reports 1993, 2003 and 2007).

In spite of these signs of change, however, by 2006 ABN AMRO was again under pressure, leading senior management to consider a merger with a stronger partner. Initially, though, the Dutch authorities preferred a 'Dutch solution', resulting in some talks with ING, a Dutch bank-insurer. However, ING abandoned its plan to make an offer because of the mounting share price of ABN AMRO, which had risen from 23 to 27 Euro. Thereafter, ABN 
AMRO's board decided to seek a merger with Barclays, which made a bid in April 2007, precipitating a takeover battle between Barclays and a banking consortium consisting of Royal Bank of Scotland, Banco Santander and Fortis. Finally, the banking consortium bought ABN AMRO in 2007 at what many regarded as a highly inflated price at the top of the market, splitting up the bank just as the global credit crunch hit the financial sector. On 4 October 2008, the Dutch state bought Fortis Bank Nederland, ABN AMRO Nederland and the Dutch insurance activities of Fortis, A capital injection a week before by the states of Belgium, the Netherlands and Luxembourg had been unsuccessful, as clients continued to remove their money from Fortis after the state intervention. By November 2008, the Dutch state had arranged a full merger between Fortis Bank Nederland and ABN AMRO Nederland, under the brand name ABN AMRO.

\section{Structure}

In the period leading up to the merger between ABN and Amro, both banks had used an international divisional structure to organise their expanding activities. Although this structure resembled the multidivisional form as defined by Whittington and Mayer (2000), it differed in important respects. The structure consisted of several divisions, of which the domestic and international, with their branch networks and subsidiaries, were the most visible, as they employed most of the staff. The activities of the functional divisions, such as securities, multinational relations, personnel, administration and risk management, were mostly performed at head office by a hierarchical layer of senior executive vice presidents, with an Executive Board responsible for long-term planning and strategy. However, while this represented a decentralised structure, in effect there was close co-ordination and communication between the head office and the branches and subsidiaries, both domestic and international, revealing the existence of a hybrid structure that was neither M-form nor totally centralised. This hybrid structure, which was also retained after the 1990 merger, arose from the need for more effective risk management than was necessary in manufacturing firms, because in having to meet basic solvency requirements across its activities, it was obliged to supervise the new ventures very closely.

During the 1990s, given the growing importance of the Investment Banking \& Global Clients division, a matrix organisation was adopted, in order to support the bank's goal of becoming a universal bank. In this organisation, the profit-centres were supported by products of the investment banking operations, while the functional divisions and risk management were still performed at head office. However, while cost controls and accountability should have been important pillars of this strategy-structure combination, ABN AMRO often had no clear picture of actual profits or costs at the divisional levels. Moreover, directors were never penalized for non-performance (Jonker 2008), indicating a need for greater organisational clarity.

In 2000, the bank abandoned its matrix organization, replacing it with a structure based on three worldwide strategic business units (SBUs) which were largely independent. Indeed, not only was the board reduced in size and obliged to focus solely on long-term planning, acquisitions and synergy issues, but all operational responsibilities, including risk management, devolved to the SBUs. This also coincided with the new emphasis on 'management for value', providing the board with greater insights into the true value of its operations, indicating that ABN AMRO was by then much more like an M-form, with complete decentralization of operations to divisions and centralized control over strategy. Although after 2005 the business was divided into five geographic divisions and two global 
divisions (private clients and global clients), ABN AMRO continued to operate as an Mform.

\section{Ownership}

Although no detailed information is available on the ownership of shares, other than the filings under the Disclosure of Major Holdings in Listed Companies Act, throughout this period ABN and Amro were joint stock companies with mostly dispersed ownership and a few larger stakes owned by other financial institutions. In 1983, the financials together had a 10 per cent stake in ABN and 15 per cent in Amro. Throughout the 1990s, while ABN AMRO had six financial companies as blockholders with more than $5 \%$ stakes, due to the existence of legal control-limiting mechanisms, these shareholders had little influence on the company and ABN AMRO is more accurately classified as a management-controlled bank. The share capital was divided into ordinary and preference shares, with the latter amounting to four times the nominal value of the ordinary shares and thus four times the voting rights (ABN AMRO Annual Report 2003). The preference shares were issued at a much lower price to an 'administration office foundation' (Stichting Administratiekantoor), which in turn issued non-voting certificates to friendly financials such as Aegon, Fortis, Delta Lloyd Leven, ING, Rabobank and investment fund De Zonnewijser. The friendly financials agreed to obtain only preferential dividend rights, while the foundation kept the voting rights. Given that many ordinary shareholders do not generally attend the annual general meeting, the votes controlled by the foundation guaranteed the executive board a majority of votes during the AGM. In 2004, this difference in voting rights was rectified, but at the same time the number of preference shares increased as well.

It is important to remember that this information on ownership trends represents primarily the act of investment rather than that of seeking management control, which left ABN AMRO free to run itself with foreign capital. ABN AMRO's outstanding ordinary shares were mainly held by institutional investors, which possessed around 80 per cent of the company during the 1990s. ING Group was the only 'friendly' shareholder that, apart from preference shares, also owned more than 5 per cent of ABN AMRO's ordinary shares, the bulk of which came increasingly to be held by foreigners.

The ownership structure changed when the bank was taken over by Royal Bank of Scotland, Santander and Fortis, as they acquired all ordinary and preference shares. In 2008, following the severe financial crisis, the Dutch state intervened in the domestic banking sector, resulting in the state acquiring the Dutch part of ABN AMRO formerly owned by Fortis. Ultimately, though, this part of the business moved into state ownership, such were the deep-seated problems besetting Dutch banking.

\section{Barclays Group Plc: Strategy, structure and ownership 1973 - 2007.}

Barclays Group plc traces its company history back to a goldsmith business that began in Lombard Street, London, in the late-seventeenth century. Over the intervening three centuries, the partner families (mostly Quakers) expanded the business through organic growth, mergers and acquisitions, taking advantage of the financial and business opportunities granted first by British imperial expansion and also by English industrialisation. Barclays had established itself as one of the dominant British banking establishments, with offices and branches in imperial possessions around the world, becoming one of the 'Big Five' banks in the UK which dominated the retail banking scene for much of the twentieth 
century. The conversion of the British Empire into a Commonwealth of independent countries created challenges for the bank, while a highly conservative culture limited its ability to cope with the rapid rate corporate change that was required by the 1970s.

\section{Strategy}

Although Barclays has consistently pursued some long-term goals, such as a $15 \%$ annual return on shareholders' funds, many important strategies appear to have been reactive rather than proactive. Not surprisingly, the successful proactive strategies received strong support from top management and were allowed time to bring them to reasonable levels of return (for example, the Barclaycard credit card programme). This fitted in well with the highly conservative strategy that was underpinned by a strong UK banking cartel which survived until 1973, allowing senior management to state publicly that their goal was not to maximize profits but to make 'satisfactory profits' (Ackrill and Hannah 2001). Indeed, Barclays was less diversified than the four other major UK banks, as $82.68 \%$ of its income stemmed from interest.

Until the cartel was broken up by government and Bank of England policy in 1973, competition between UK banks was mostly at branch level, for market share, rather than in price terms (Ackrill and Hannah 2001). New international currency arrangements affected important elements of strategy and structure, leading to the consolidation in 1973 of Barclays Bank International (BBI) which included all non-UK operations under one banner (Ackrill and Hannah 2001). Another crucial change in the 1970s was the adoption of the 1977 EEC Banking Directive, in the form of the 1979 Banking Act, directly influencing British banking in three ways. Firstly, it legally defined a 'bank' and imposed a new regulatory framework that guaranteed $75 \%$ of accounts holding less than $£ 10,000$, forcing Barclays to provide clear guarantees that this was available. Secondly, the government ended controls on the movement of sterling, allowing foreign competitors to enter the UK domestic lending market and pushing loan demand off-shore. These two changes brought the third: since British corporations could now invest overseas more easily, the division between foreign and domestic business which Barclays had established in 1973 with the creation of BBI became irrelevant.

While all these changes were taking place, Barclays' extensive exploitation of technology further eroded the cartel, especially with 1960s innovations such as Barclaycard (Britain's first mass-market credit card) and the introduction of automated teller machines (ATMs). Systematic use of machines qualitatively differed from earlier competitive practices such as branch-expansion and labour-intensive customer service, significantly increasing Barclays' competitiveness. For all UK banks a continuing and sometimes troubled relationship with rapidly-improving technology eventually lowered transaction costs, reduced staffing, and increased customer access outside of business hours. After initial problems, Barclays' attitude toward technology matured into cautious appreciation of its (expanding) power, while more recently it has been used as a key tool in reducing costs. The 1970s consequently saw a rapid change in strategy: by 1983, only $28.46 \%$ of Barclays' income stemmed from interest, pushing it into the dominant non-interest strategy category. This spike in non-interest income in 1983 results from 'lower overall spreads and increasing reliance on more expensive wholesale funds' in an environment where commissions and fee income improved and costs were closely monitored (Financial Times 1983). This meant that the Bank could not borrow at low rates through the interbank system and lend out at higher rates to clients. The following year tax law changes (when 'capital allowances' were phased out) 
meant that big UK clearing banks, including Barclays, were assessed by a one-time charge which nearly equalled the previous year's pre-tax profits (Ackrill and Hannah 2001). From 1984-1986, newspaper reports clearly indicated that non-interest income in British banking had increased while costs had been more strictly controlled (Financial Times 1985). While the non-interest income spike was not sustained, the pendulum had swung decisively from an extremely high reliance on interest income (over $80 \%$ in 1973) to less than one-third (28\%) a decade later. However, after establishing a high base for its fee and commission income generation in the mid-1980s, Barclays moved toward a balance between interest and noninterest income, whereby each figure has hovered between $45-55 \%$ since the early 1990 s, suggesting a diversified strategy. After 1983, the interest/non-interest income ratio shows more stability than those of the other two banks, suggesting that Barclays had a more balanced income stream that relied less heavily on commission and fee income.

Attracting new customers became the mission of the 1980s, as rising affluence meant that more people needed bank services. Entering the UK mortgage market also drew retail customers into branches: ' $[t]$ he main aim was to provide branded, packaged, standardized, financial services through the branches, reducing costs, while retraining staff in marketing' (Ackrill and Hannah 2001: 254). As part of this search for new markets and customers, and anticipating the October 1986 'Big Bang' in the City of London, Barclays expanded into merchant banking activities, with the purchase of stock-trading companies de Zoete and Wedd (later Barclays de Zoete Wedd, or BZW) and into market-making and stock-brokering, even though little effort was put into a proper investment appraisal (Ackrill and Hannah 2001, Vander Weyer 2000, Plender 1987). Indeed, both Jones (1993) and Vander Weyer (2000) have claimed that BBI had consistently made significant investment mistakes by entering markets such as California without adequate forethought or planning. A 'one-bank' strategy was adopted in 1985, which terminated the separate existence of Barclays Bank International (BBI) and integrated all operations into Barclays Group Plc. This was part of the board's desire to create a world-leading bank on a par with the biggest American competitors (Vander Weyer 2000), which also gave the central board greater control of international ventures and stronger emphasis on merchant banking activities. Barclays raised $£ 921 \mathrm{~m}$ from shareholders in 1988 to fund this expansion, representing a $20 \%$ gain in funds. Contemporary observers considered the fund-raising a 'strategic master-stoke' at a time when the economy was slipping into recession.

Like other British banks such as National Westminster and Midland, Barclays had entered the American market in the 1960s as much to avoid missing out on future opportunities as because they felt capable of making a profit (Jones 1993). The segmentation of the American financial market, complex banking laws which differed between states, and the entrenched competition by similarly sized banks made profitability very difficult. What had seemed like an expanding market in California quickly cooled, and even with occasional takeovers of existing banks Barclays could only at best break-even. As the recession of the late-1980s continued into 1990, Barclays scaled back operations to concentrate on key areas of strength and expertise, while the unsuccessful California operations were sold off to replenish reserves. During the 1990s, however, a two-pronged strategy was pursued: expansion in the world's key markets and an emphasis on investment, rather than retail, banking (which the Bank believed, along with its Swiss and Dutch counterparts, was delivering diminishing returns). The Group's ambition consequently moved to a global level, offering a range of services for international customers in all major financial centres from its three divisions (Banking, BZW, and Service Businesses), while at the same time seeking synergies across the Group in the context of robust market conditions. 
By 2001, however, the board was ready to elaborate a new strategy, setting four key priorities which they modified and reiterated in 2004. Their key aims were to build the best bank in the UK, grow their global product businesses (such as credit cards, investment banking, institutional money management and wealth management), extend the Bank's presence in select retail and commercial banking markets outside the UK, and create operational excellence (Barclays Plc Annual Reports 2004, 2008). Crucially, international activities were a consistent priority, with Barclays benefitting significantly from the global financial 'bubble' that burst in 2008. Although it failed to merge with ABN AMRO in 2007, which proved to be a blessing in disguise, prominent features of this international strategy were collaboration with the China Development Bank and acquiring the crippled Lehman Brothers investment bank in 2008. Barclays remained independent of the UK government support scheme during the credit crisis (in contrast to competitors Royal Bank of Scotland Group, Lloyds TSB, and HBOS), allowing the board to claim that it was the strongest UK bank.

\section{Structure}

From an organizational perspective, Barclays has sought an appropriate structure to cope with the various strategies enacted since 1970. In 1973, the Bank consolidated all nonUK activities into Barclays Bank International (BBI), with domestic activity operating as Barclays Bank Ltd. As this reduced the operational autonomy of different overseas businesses, it represented a move away from the M-form. Even though this attempted integration created internal tensions (Vander Weyer 2000), it provided the basis for further connectivity that emerged in 1985 when Barclays Group Plc was created, marking a new phase of centralizing corporate management and the abandonment of regionally-based boards of directors. By 1987, the thirty-two members of the London-based board of directors held ultimate control over the activities of the Group's worldwide business. Shifting divisional pieces (for example, transferring the money-market business to BZW in 1992) was aimed at either achieving efficiencies of scale and scope, or taking advantage of human skills which were abundant in some areas but scarce in others. Since 2000, Barclays Group has reshuffled or renamed its 'strategic business units' with bewildering regularity, some of which lasted only a matter of months. Like the other banks analysed above, the corporation stayed in structural flux throughout the early 2000s as constant realignments allowed only core business units, such as UK personal retail banking, to maintain a sense of consistency.

\section{Ownership}

Barclays' ownership structure throughout the period reflects the dispersed ownership pattern typical of publicly-traded international companies, with no shareholder holding more than $10 \%$ of the company in 1973, a situation that persisted through 2007 . By that time, only two shareholders (Qatar Holdings with 6.4\% and Axa with 5.5\%) held more than 5\% of the 8.37 billion shares outstanding (Barclays Plc Annual Report 2008), while 62\% of all shareholders possessed between 101-500 shares (68\% in 2003). The corresponding figures for 1983 and 1993 were $37.8 \%$ and 20.1\%, respectively. These numbers demonstrate that the proportion of individuals holding a modest number of shares (between 101-500 shares per shareholder) dropped sharply during the second half of the 1980s, a trend which reversed entirely in the 1990s and early 2000s as individual retail investor access improved. By 2003, more dispersed ownership existed than a decade earlier, with the exception of very few extraordinarily large holdings by institutional fund managers seeking steady income streams. 


\section{Performance across the three banks.}

In the original Harvard studies, as well as in Whittington and Mayer's work (2000), a related diversified strategy combined with the multidivisional form is considered to provide superior performance to other strategy-structure combinations. Although they do not provide much substantiating evidence to support their claims, Whittington and Mayer (2000: 187) state that: 'By and large, the multidivisional offers the best chance of steady and respectable financial returns'. We consequently need to consider how the strategic orientation towards related diversification into investment banking and the structural restlessness of the three banks analysed here played out in terms of different performance measures. Comparing bank performance across the different economies presented challenges which were accentuated by the shifting relative valuations of currencies and the introduction of the Euro in the Netherlands. Thus, our analysis here deals primarily with important banking ratios, instead of issues of absolute size of assets, equity, or advances/loans.

\section{Insert Table 1 here}

Both in terms of Return on Assets (RoA) and Return on Equity (RoE), Barclays was markedly more profitable in 1973 and 1983 than the four continental banks, with an RoA of $0.78 \%$ in 1973 and $0.85 \%$ in 1983 (see Table 2). The corresponding figures for the four continental banks were around 0.4\% in 1973. By 1983, AMRO's profitability had suffered considerably (0.18\%), while ABN remained at around $0.29 \%$. The two Swiss banks' profitability, on the other hand, had risen to approximately $0.6 \%$ by 1983 . The picture had considerably changed by 1993, by which time the two Swiss banks had become the most profitable operations, with an RoA of $0.68 \%$ and $0.67 \%$, while Barclays had fallen to just under $0.4 \%$, where it would remain through the 1990s until 2007. ABN AMRO also had an RoA of around $0.4 \%$ in 1993 , but managed to increase profitability to almost $0.97 \%$ in 2007 , while UBS experienced a decrease in RoA over the same period $(0.46 \%$ in $2003 ;-0.19 \%$ in 2007). One explanation of Barclays' historically poor RoA figures for 1993 and 2003, which are dramatically lower than for 1983 when the expansion into full-service financial management began, result from the explosive growth in assets rather than management's inability to generate healthier returns. Indeed, Barclays' asset basis grew earlier than that of the other banks, although this does not explain why Barclays' RoA was still below the other banks' RoA in 2003, when all three remaining banks had considerably larger and comparable asset bases (measured as a proportion of equity) than in 1993 (see Table 2).

In terms of their Return on Equity (RoE), the picture is similar during the first two sample years: with RoEs of $15 \%$ and $20 \%$, respectively, Barclays was far more profitable than the continental banks (whose RoE was below 10\% in both years). Barclays' RoE had fallen markedly to around $10 \%$ by 1993 , when all the other banks' ratios remained around $10 \%$ (with the notable exception of the old UBS, whose organic growth strategy resulted in comparatively poor performance, which partly explains why it became a target for raiders like Ebner). A steep improvement in the Dutch and Swiss banks' performance over the next decade led to RoEs of above 15\% for both of them in 2003, while the Barclays' figure further declined to around $11 \%$. ABN AMRO continued its impressive increase, reaching a RoE of above $30 \%$ in 2007, at a time when Barclays had recovered some of its profitability (15\%), and UBS paid the price for its aggressive expansion into the sub-prime market with a slump to $-12 \%$. 
It should also be noted that the merger of ABN and Amro, as well as that of SBC and UBS, both had a strong impact on profitability. ABN AMRO's RoE increased significantly after the merger, suggesting that while management may have seen costs rise, its expansion into more profitable businesses paid off for shareholders. Likewise, the new UBS reported strong RoE figures of $28.2 \%$ for $2004,39.7 \%$ for 2005 and $25.8 \%$ for 2006 , before the subprime financial crisis destroyed profits, notably in the securities-backed mortgage business (UBS Financial Report 2007). Arguably, the banks' increased profitability during the 1990s and early 2000s resulted not only from a strategic reorientation into more profitable businesses, but also an increasing shareholder-orientation, which led to share buy-back programmes and nominal capital pay-backs that increased RoE, but left other performance measures unchanged.

A third measure of performance, the efficiency ratio comparing revenue to expenses, seems for all three banks to reflect the increasing staff costs linked to the expansion of their investment banking business. Indeed, this ratio has fallen considerably for UBS (from almost 2 in 1993 to under 1 in 2007). Similarly, ABN AMRO's efficiency ratio fell from 1.5 in 1993 to around 1 in 2007, while Barclays maintained a higher efficiency level at around 1.5 in 2007, but down from 1.7 in 2003. The declining ratios are certainly in part explained by increasing staff costs, notably in US subsidiaries. These staff costs became a problem especially for ABN AMRO after the recession of the early 2000s, significantly affecting performance in spite of the market's enormous growth.

A striking feature of the evolution of performance is that Barclays was far more profitable during the early part of the period analysed here, while Dutch and Swiss banks caught up quickly, outperforming the UK bank for most of the 1990s and early 2000s. This seems to indicate that their more aggressive expansion into investment banking and related activities was - at least in the short run - very profitable. It may also have to do, however, with the spread of shareholder-orientated and value-based management practices, which for the first time put pressure on continental managers to pay closer attention to profitability measures such as RoA and especially RoE.

Overall, ABN AMRO appears to have been the most successful company over the period analysed, with a steady increase in both RoA and RoE. Ironically, though, it was this bank that disappeared in 2007 through a hostile takeover. Barclays started from a very high level, but has experienced a constant decline in profitability since 1983; only after 2003 did its performance improve again. While the recent credit crisis certainly thwarted Barclays' ambitious multi-year performance goals announced in 2007 (Barclays 2007 Annual Report), it weathered the storm of the financial crisis much better than the two other banks, revealing the somewhat more balanced strategy mentioned above. UBS, on the other hand, after several years of record profit levels since the mid-1990s, suffered considerably from the subprime crisis and reported negative returns on assets and equity in 2007.

\section{Conclusions}

When assessing the three case studies in the context of an SSOP perspective, it is apparent that all aspired to be 'global and universal' banks in the 1980s; all of them, either individually (UK) or through their constituent former businesses (Netherlands, Switzerland) adopted a strategy of merger and acquisition, augmented by internal (organic) growth to achieve these aims (see Table 2). This reveals a remarkable convergence on a strategy of 
related diversification and internationalisation, given that all three banks pursued different strategies during earlier periods (with the Dutch banks formerly relying on commercial shortterm credit, the Swiss banks following a German-style universal banking, and Barclays historically pursuing an internationally orientated strategy). The European entrance of relatively lean American competitors in the 1980s, competitors firmly based in the much larger US market, to a significant extent explains this strategic convergence, because the competition hit the European banks very hard, prompting all to make their own investments in the American market (Channon 1986). Barclays, for example, went for both retail and institutional banking, albeit with mixed results that led to the sale of major US-based businesses, whereas ABN AMRO combined retail with investment banking and UBS tended to lean more towards investment banking by acquiring brokerage houses or investment banks of middle size and building them up with internal resources.

\section{Insert Table 2 here}

Underpinning all strategies appears to be the belief that the sheer size of corporate assets was a key component to efficiency - or at least survival - in the banking sector; more apt would have been examinations of productivity, considerations of political or economic stability in certain international markets, and questioning the relevance of new lines of business to the firm's core competencies. Thus, it seems that all banks stuck to their strategy throughout the 1990s despite clear evidence at times that they were not successful. All identified (and sought to enter) wealth/asset management as a high-margin growth sector, recognising the improved affluence of the late-twentieth century and the growing number of individuals possessing considerable personal wealth that required administration. Extensive deregulation allowed them to pursue a larger number of these people than ever before. They also entered or expanded their presence in investment banking for corporate clients, thereby gaining access to equity trading. The financial industry consequently reacted to the increasing market integration and the single European market with increasing diversification. This is remarkable different to the manufacturing sector, where the effect of the single market appears to have been a re-concentration on companies' core business (Rondi et al 2004). On the other hand, all of the banks appeared to have overextended themselves, either geographically and/or otherwise (mostly through mergers) during the growth period of the mid-1990s. More recently, though, all of the banks have run into trouble: ABN AMRO came apart and was partly bought by the Dutch government; Barclays, like all English banks, required state guarantees regarding the security of the financial system, but retained dispersed ownership; and UBS, having secured a number of high-net-worth American accounts by encouraging tax-dodging, faced legal investigation and sparked off a major political crisis. This turbulence during the first decade of the new century caused all banks to concentrate anew on their core businesses, which continued to include retail savings/banking for individuals or - in the case of UBS - at least reconsider their international presence.

As we noted earlier, at the level of structure, however, the determined pursuit of international expansion and diversification strategies into supposedly more profitable businesses did not go together with an equally clear preference for any particular structure. Indeed, all three banks undertook several significant restructurings during the decades in question as they adjusted to internal and external regulatory requirements, entry and exit from specific markets and lines of business, and increasing competition. This was by no means a linear process in which a given structure followed automatically a new strategy, but it resembled a 'trial and error' process in which the banks experimented with different forms in order to take on the challenge of integrating new businesses and new companies into the 
existing bank. As an example, both ABN AMRO and UBS experimented briefly with a matrix structure during the early 1990s. The growing pains of merging two large banks and integrating their corporate structures involved considerable management time and attention, prompting what might be retrospectively interpreted as 'consolidation' restructurings to wipe away all remnants of the former companies' forms and embark on a uniquely new ABN AMRO or UBS corporate identity. This process culminated in the case of UBS during the early twenty-first century, when an explicit 'One Bank' strategy was adopted, a process that Barclays had initiated twenty years earlier.

Overall, the new structures seem to show signs of increasing decentralisation of operational activities and profit responsibility, notably through the creation of strategic business units (SBUs). None of the banks adopted a pure and stable M-form. Some changes seem to point in the direction of what Whittington and Mayer (2000: 83-4) have called the 'network multidivisional', where the separation between divisions is less strict than in the classic manufacturing-industrial multidivisional. Notwithstanding this evidence, it is above all apparent that the multidivisional form has not yet proved to be the 'final resting point' for these three banks that it was in the case of Whittington and Mayer's top 100 manufacturing firms in France, Germany and the UK (Whittington and Mayer 2000). One reason for this could well be that bank managers are more reluctant than their counterparts in manufacturing companies to allow extensive divisional autonomy due to requirements of risk management and sustaining legally-enforceable reserve requirements.

In terms of ownership, we observed a trend towards increasing institutionalisation of ownership, a process that is congruent with the overall evolution of ownership structures in most advanced economies. Despite the emergence of new blockholders owning sometimes considerable stakes, generally the banks have been characterised by highly dispersed ownership structures, with ABN AMRO being an exception since 2008.

Finally, with specific regard to performance it appears that financial performance has become more important for the continental European banks over the period analysed. Indeed, profitability in terms of RoA and RoE (see Table 2) has markedly increased in both cases. This can certainly be attributed to a fundamental change in the orientation of these banks towards more profitable businesses. The numerous mergers and consequent restructurings seemed, however, to have resulted in severe problems in sustaining profitability during the 1990s and early 2000s. Both ABN AMRO and the old UBS struggled with below-par performance and rapidly expanding costs during much of the 1990s. Only radical shareholder-value oriented strategies and aggressive acquisition of new funds had in both cases the effect of bringing about a true quantum leap in profitability. Barclays experienced arguably somewhat less radical strategic reorientations, thereby limiting its profit growth.

In short, the SSOP perspective reveals several interesting dynamics within the European banking industry in a context of increasing market integration which shed new light on the underlying framework. Firstly, while we observe a remarkable convergence in terms of bank strategies across the three corporations, we do not find any evidence that organisational structures closely follow this evolution. This leads us to question the stipulated match between a diversified strategy and the M-form, begging the question of industryspecific factors that explain this situation.

Secondly, we find a very striking contrast between the bank managements' unwavering pursuit of diversification and internationalisation strategies since the 1970s and 1980s and the 
'experimental' approach to organisational structure. Indeed, while all three banks pursued a comparable expansion and diversification strategy throughout the 1980s and 1990s, sticking to this strategy despite mixed results, reorganisations and restructurings of the three banks became a regular event. Both findings - pursuit of a clearly suboptimal business strategy and restless restructuring of the organisation - contradict the Chandlerian idea of rational managers and a 'logical', virtually inevitable link between a given business strategy and an organisational form.

The stubborn pursuit of aggressive growth strategies, in spite of clear signs of their unsustainability, reveals that rather than efficiency-seeking behaviour, the strategic reorientation of European banking was marked by a rather uncritical attitude towards these strategies once they were in place. Indeed, all three banks developed strategies during the late 1980s to which they adhered despite signs that the strategies failed to give them a competitive edge. This was clearest in the case of ABN AMRO, where the new strategy failed for a long time to increase profitability. On the contrary, internal reports even suggested that a return to more traditional business sectors would have been a more promising alternative to the 'Go Global' strategy. Similarly, despite very limited success, UBS clung to its new strategy throughout the 1990s until a merger with SBC became inevitable, while Barclays' expansion into the US market happened despite widespread reservations about the viability of this strategy. Moreover, senior managements appear to have followed these strategies regardless of their long-term commercial viability. One possible explanation for this behaviour may arise from the material advantages that managers themselves received from engaging in these more lucrative businesses, where salaries and bonuses were much higher than in traditional commercial and retail banking. This too seems very much at odds with the image of efficiency-seeking managers that the Chandlerian tradition posits as the main driver of strategic and organisational change in modern capitalism, confirming once again the fundamental differences between trends in manufacturing industry and financial services. 


\begin{tabular}{|c|c|c|c|c|c|c|}
\hline & & Revenues/ & & & Equity/ & Loans/ \\
\hline \multicolumn{2}{|l|}{ Switzerland: } & Expenses & ROE & ROA & Assets & Assets \\
\hline UBS AG & 2007 & 0.9580 & -12.3198 & -0.1929 & 0.0157 & 0.1478 \\
\hline UBS AG & 2003 & 1.3258 & 18.0133 & 0.4607 & 0.0256 & 0.1533 \\
\hline SBC & 1993 & 1.9521 & 10.3968 & 0.6824 & 0.0656 & 0.5376 \\
\hline SBC & 1983 & 5.6655 & 8.4190 & 0.5684 & 0.0675 & 0.5871 \\
\hline SBC & 1973 & 4.1982 & 8.7545 & 0.4304 & 0.0492 & 0.3729 \\
\hline UBS & 1993 & 1.9189 & 7.1241 & 0.6692 & 0.0939 & 0.7067 \\
\hline UBS & 1983 & 1.0694 & 8.5908 & 0.5827 & 0.0678 & 0.5648 \\
\hline UBS & 1973 & 1.0778 & 9.0582 & 0.4111 & 0.0454 & 0.3308 \\
\hline \multicolumn{7}{|c|}{ United Kingdom: } \\
\hline BARCLAYS & 2007 & 1.5308 & 15.6885 & 0.4151 & 0.0265 & 0.3141 \\
\hline BARCLAYS & 2003 & 1.7112 & 11.1819 & 0.4155 & 0.0372 & 0.6582 \\
\hline BARCLAYS & 1993 & 1.5317 & 11.0870 & 0.3933 & 0.0355 & 0.5779 \\
\hline BARCLAYS & 1983 & 1.0902 & 17.5654 & 0.8582 & 0.0489 & 0.7867 \\
\hline BARCLAYS & 1973 & 1.4793 & 15.2989 & 0.7870 & 0.0514 & 0.5955 \\
\hline \multicolumn{7}{|l|}{ Netherlands: } \\
\hline ABN AMRO & 2007 & 1.0912 & 32.4823 & 0.9730 & 0.0300 & 0.5584 \\
\hline ABN AMRO & 2003 & 1.3545 & 18.8604 & 0.5640 & 0.0299 & 0.6346 \\
\hline ABN AMRO & 1993 & 1.5081 & 10.5753 & 0.4122 & 0.0390 & 0.8064 \\
\hline ABN Bank & 1983 & 1.5064 & 10.5146 & 0.2896 & 0.0275 & 0.8876 \\
\hline ABN Bank & 1973 & 1.3598 & 10.0457 & 0.2852 & 0.0284 & 0.8139 \\
\hline AMRO Bank & 1983 & 1.6212 & 6.9229 & 0.1705 & 0.0246 & 0.8866 \\
\hline AMRO Bank & 1973 & 1.3254 & 12.6567 & 0.3706 & 0.0293 & 0.8661 \\
\hline
\end{tabular}




\section{Bibliography.}

ABN Bank. Annual Reports 1973-1990.

Ackrill, M. \& Hannah, L.. (2001). Barclays : the business of banking, 1690-1996.

Cambridge: Cambridge University Press.

ABN AMRO Bank. Annual Reports 1990-2008.

Amro Bank. Annual Reports 1973-1990.

Bank Julius Bär. (1991). Besitzverhältnisse von Schweizer Aktien. Marktübersicht Schweiz (1), 1-43.

Bank Julius Bär. (1996). Besitzverhältnisse von Schweizer Aktien. Marktübersicht Schweiz (2), 22-34.

Barclays Group. Annual Reports 1973, 1983, 1993-2008

Battilossi, S. \& Cassis, Y. (Eds) (2002). European banks and the American challenge: competition and cooperation in international banking under Bretton Woods. Oxford: Oxford University Press.

Berendsen, C. (1999). Global ambitions, ABN AMRO Bank 1990-1999. In J. De Vries et al (Eds), Worldwide banking, ABN AMRO Bank 1824-1999 (pp. 449-488). Amsterdam: ABN AMRO Bank.

Burkhalter, T. (2001). Einheitsaktien ihre Einführung und Existenz im Lichte der Diskussion um Corporate Governance. Zürich: Schulthess.

Calomiris, C.W. (2002). Banking approaches the modern era. Regulation 25 (Summer).

Calomiris, C.W. (2000). US Bank deregulation in historical perspective. New York: Cambridge University Press.

Canals, J. (1993). Competitive strategies in European banking. Oxford: Clarendon Press.

Canals, J. (1997). Universal banking: international comparisons and theoretical perspectives. Oxford: Oxford University Press.

Channon, D.F. (1977). British banking strategy and the international challenge. London: Macmillan.

Channon, D.F. (1986). Cases in bank strategic management and marketing. New York: John Wiley \& Sons.

Financial Times, 15 August, 1983.

Financial Times, 2 August, 1985.

Financial Times, 23 March , 2009.

Graf, U. (1993a). Basic Conditions: The Regulatory Framework and Public Policy Developments since 1980. In N. Blattner (Ed.), European Integration and the Swiss Financial Centre (pp.45-73). Chur: Verlag Rüegger.

Graf, U. (1993b). Elements of Conduct in Swiss Banking and Developments since 1980. In N. Blattner (Ed.), European Integration and the Swiss Financial Centre: 125-135. Chur: Verlag Rüegger.

Jones, G. (1993). British Multinational Banking, 1830-1990. Oxford: Clarendon Press.

Jonker, J. (2008). Scale at any price. The rise and predictable demise of ABN AMRO, 19602006. Utrecht: (working paper).

Klompe, M.E. \& van der Vossen, J.W. (1990). Zestig jaar bankentoezicht: van vrijwillige samenwerking tot Tweede Banken richtlijn. Amsterdam: De Nederlandsche Bank.

Kroszner, R.S. (2001). The motivations behind banking reform. Regulation 24 (Summer).

Leeuw, J. de. (1996). Financiële conglomeraten in Nederland. Serie Bank- en Effectenbedrijf 38. Amsterdam: NIBE.

Leitz, C. (2008). Die Entstehung von UBS. Unternehmerischer Wandel und der Weg zur Weltspitze. Zurich: UBS. 
Loderer, C. \& Zgraggen, P. (1998). Der Stimmrechtskampf von 1994 zwischen UBS und BK Vision /Analyse einer für alle UBS-Aktionäre verlustreichen Auseinandersetzung/ Ankündigung der Einheitsaktie. Neue Zürcher Zeitung, May 16, 29.

Müller-Stewens, G. \& Shivacheva, R. (2006). UBS: The Way to the Top in Global Banking (1998 - 2005). Phase II: Excelling at the "Seamanship Test" (2001 - 2002). St. Gallen: University of St. Gallen.

Plender, J. (1987). London’s Big Bang in International Context. International Affairs, 63(1), 39-48.

Ravara, C. (1999). Allfinanz. Nicht neu, aber mit Zukunft. Credit Suisse Economic Briefings, 12(October), 1-18.

Rondi, L., Sleuwaegen, L. \& Vannoni, D. (2004). Changes in the Industrial and Geographical Diversification of Leading Firms in European Manufacturing. In A. Dierx, F. Ilzkovitz \& K. Sekkat (Eds), European Integration and the Functioning of Product Markets (pp. 61-83), Cheltenham: Edward Elgar.

Schaub, V. (1992). Konzernpolitik im Schweizer Bankbereich. Eine Darstellung der Determinanten und Ausgestaltungsmöglichkeiten unter Berücksichtigung ausgewählter Schweizer Bankkonzerne. Bern: Haupt.

Schröter, H. (1996). Cartelization and Decartelization in Europe, 1870-1995 : Rise and Decline of an Economic Institution. Journal of European Economic History, 25(1), 129-153.

Smit, J. (2008). De Prooi. Blinde trots breekt ABN AMRO. Amsterdam: Prometheus.

UBS communiqué, 12 August 2008.

Vander Weyer, M. (2000). Falling Eagle : the decline of Barclays Bank. London: Weidenfeld \& Nicolson.

Vanthoor, W. (2005). The King's eldest daughter. A history of the Netherlandsche Bank, 1914-1998. Amsterdam: Boom.

Westerhuis, G. (2008). Conquering the American market. ABN AMRO, Rabobank and Nationale-Nederlanden working in a different business environment, 1965-2005. Amsterdam: Boom.

Whittington, R. \& Mayer, M. (2000). The European corporation. Strategy, structure, and social science. Oxford: Oxford University Press.

Wirth, M. (1993). The Industrial Structure and the Performance of Banking in Switzerland. In N. Blattner (Ed.), European Integration and the Swiss Financial Centre (pp. 75-124). Chur: Verlag Rüegger.

Zanden, J.L. van \& Uittenbogaard, R. (1999). Expansion, internationalisation and concentration, 1950-1990. In J. de Vries et al. (Eds), Worldwide banking, ABN AMRO Bank 1824-1999 (pp. 335-391). Amsterdam: ABN AMRO Bank. 
Table 2. Classification of banks 1973-2007 according to Whittington and Mayer's definitions

\begin{tabular}{|c|c|c|c|c|c|c|c|c|c|c|c|c|c|c|c|}
\hline & & & trate & egy & & & & ruct & ure & & & & Dwner & & \\
\hline & \begin{tabular}{|c}
197 \\
3
\end{tabular} & \begin{tabular}{|l|}
1 \\
9 \\
8 \\
3
\end{tabular} & \begin{tabular}{|c|}
199 \\
3 \\
\end{tabular} & $\begin{array}{c}200 \\
3\end{array}$ & \begin{tabular}{c|}
200 \\
7
\end{tabular} & \begin{tabular}{|c|}
197 \\
3
\end{tabular} & \begin{tabular}{|c|}
198 \\
3
\end{tabular} & \begin{tabular}{|c|}
199 \\
3
\end{tabular} & \begin{tabular}{|c|}
200 \\
3
\end{tabular} & 2007 & 1973 & 1983 & 1993 & 2003 & 2007 \\
\hline Barclays & $\mathrm{D}_{\mathrm{i}}$ & \begin{tabular}{|l|} 
\\
$\mathrm{ni}$
\end{tabular} & Div & Div & Div & $\mathrm{M}$ & \begin{tabular}{|c|}
$\mathrm{M} /$ \\
$\mathrm{U}$
\end{tabular} & \begin{tabular}{|c|}
$\mathrm{M} /$ \\
$\mathrm{U}$ \\
\end{tabular} & $\mathrm{M}$ & M & $\mathrm{P}$ & $\mathrm{P}$ & $\mathrm{P}$ & $\mathrm{P}$ & $\mathrm{P}$ \\
\hline $\mathbf{A B N}$ & $\mathrm{D}_{\mathrm{i}}$ & \begin{tabular}{|c|}
$\mathrm{D}$ \\
$\mathrm{i}$
\end{tabular} & Div & Div & Div & $\begin{array}{c}\mathrm{M} / \\
\mathrm{U}\end{array}$ & \begin{tabular}{|c|}
$\mathrm{M} /$ \\
$\mathrm{U}$ \\
\end{tabular} & $\mathrm{MX}$ & $\mathrm{M}$ & M & $\mathrm{P}$ & $\mathrm{P}$ & LD & LD & FIN \\
\hline AMRO & $\mathrm{D}_{\mathrm{i}}$ & \begin{tabular}{|c|}
$\mathrm{D}$ \\
$\mathrm{i}$
\end{tabular} & & & & $\begin{array}{c}\mathrm{M} / \\
\mathrm{U}\end{array}$ & \begin{tabular}{|c|}
$\mathrm{M} /$ \\
$\mathrm{U}$ \\
\end{tabular} & & & & $\mathrm{P}$ & $\mathrm{P}$ & & & \\
\hline UBS & $\mathrm{D}_{\mathrm{i}}$ & \begin{tabular}{|c|}
$\mathrm{D}$ \\
$\mathrm{i}$
\end{tabular} & Div & Div & $\mathrm{D}_{\mathrm{ni}}$ & U & $\mathrm{U}$ & MX & $\mathrm{M}$ & NM & $\mathrm{P}$ & $\mathrm{P}$ & $\mathrm{P}$ & & $P$ \\
\hline SBC & $\mathrm{D}_{\mathrm{i}}$ & $\mathrm{i}$ & Div & & & $\mathrm{U}$ & $\mathrm{U}$ & M & & & $\mathrm{P}$ & $\mathrm{P}$ & & & \\
\hline
\end{tabular}

\section{Strategy:}

$\mathrm{D}_{\mathrm{i}}=$ dominant (interest

income)

Div $=$ diversified (interest and non-interest income between $5 \%$ and $70 \%$ )

$\mathrm{D}_{\mathrm{ni}}=$ dominant (non-interest income)

\section{Structure:}

$\mathrm{U}=$ unitary

\section{Ownership:}

$\mathrm{P}=$ public company (no

shareholder $\geq 5 \%$ )

FIN = financial institution as

blockholder

$\mathrm{LD}=$ management controlled through

legal device

\section{Performance}


$\mathrm{M}=$

multidivisional

$\mathrm{H}=$ holding

MX =

matrix

$\mathrm{NM}=$ network

multidivisional
RoA in

$\%$

RoE in

$\%$

Table 2. (continued)

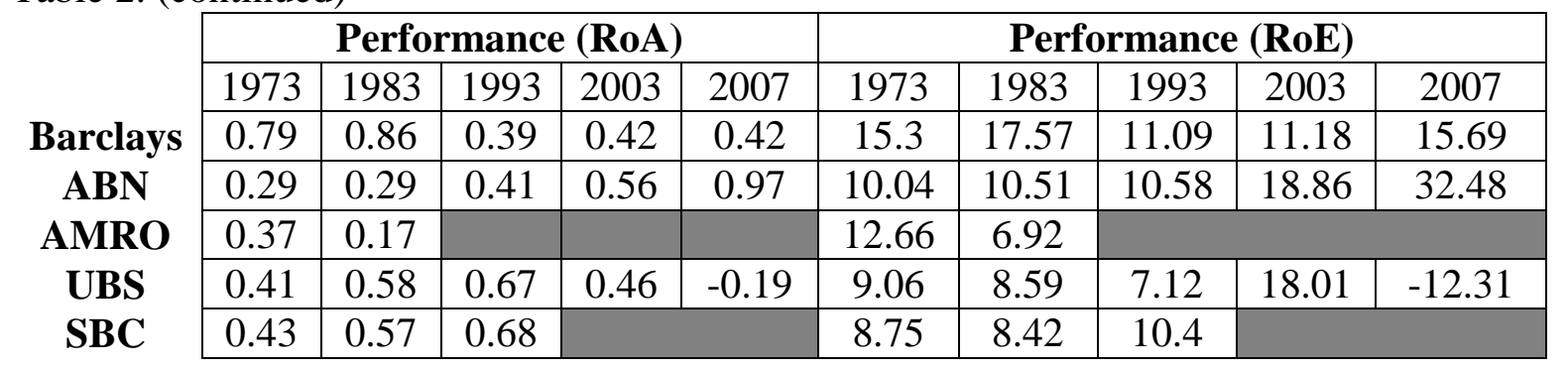

